Care: Jurnal Ilmiah Ilmu Kesehatan Vol .6, No.3,2018,hal 210-218

Tersedia online di https://jurnal.unitri.ac.id/index.php/care

ISSN 2527-8487 (online)

ISSN 2089-4503 (cetak)

\title{
Pendidikan Kesehatan Berbasis Kesehatan Multimedia Berpengaruh Terhadap Pengetahuan Tentang Reproduksi Siswa
}

\author{
Nina Nirmaya Mariani ${ }^{1}$, Lisnawati ${ }^{1}$ \\ Program Studi Kebidanan Cirebon, Poltekes Kemenkes Tasikmalaya \\ e-mail: nina.nirmaya.mariani@gmail.com
}

\begin{abstract}
Adolescent reproductive bealth education is one of the efforts to prevent acts of deviant sexual behavior since the low level of knowledge about reproductive health is likely to become a factor that affects high cases the behavior. By using multimedia, efforts to increase knowledge of adolescents will be more effective as this can be an alternative in improving students' knowledge, especially about reproductive health. This research aimed to determine the effects of multimedia in improving knowledge about a dolescent reproduction bealth among the students of class XI of SMAN 9 Kota Cirebon. This quasi experimental research used a pretest posttest with control group design. Selected using cluster random sampling, the sample size of 60 students was divided into intervention and control group with 30 students in each group. The instruments used were multimedia in the form of BKKBN copyright videos and simple media (power points), questionnaires. Data analysis in this study used paired t test to see differences in one treatment group and independent $t$-test for different treatment groups. The results showed an increase in knowledge in each group with a bigher increase in the multimedia group $(p<0.05)$. It is expected that there will be cross-sectoral cooperation in providing adolescent reproductive bealth materials using multimedia.
\end{abstract}

Keywords: health education; knowledge; multimedia; reproductive health; simple media

\section{ABSTRAK}

Pendidikan kesehatan reproduksi remaja merupakan salah satu upaya mencegah tindakan penyimpangan perilaku seksual. Rendahnya pengetahuan menjadi satu faktor yang mempengaruhi tingginya kasus perilaku seksual menyimpang. Pendidikan kesehatan dengan menggunakan multimedia akan menjadi alternatif dalam meningkatkan pengetahuan siswa khususnya tentang kesehatan reproduksi. Tujuan penelitian adalah untuk mengetahui pengaruh multimedia dalam peningkatan pengetahuan tentang kesehatan reproduksi remaja siswa kelas XI SMAN 9 Kota Cirebon. Jenis penelitian merupakan penelitian eksperimen semu (quasi experimental) dengan rancangan pretest posttest with control group design. Pengambilan sampel dengan teknik cluster random sampling. Besarnya sampel yaitu 30 siswa sebagai kelompok intervensi dan 30 siswa sebagai kelompok kontrol. Instrumen yang digunakan adalah multimedia berupa video hak cipta BKKBN dan media sederhana (power point), kuesioner. Analisis data dalam penelitian ini menggunakan paired $t$ test untuk melihat perbedaan dalam satu kelompok perlakuan dan independent t-test untuk kelompok perlakuan yang berbeda. Hasil penelitian menunjukkan adanya peningkatan pengetahuan di masingmasing kelompok dengan peningkatan lebih tinggi pada kelompok multimedia $(p<0,05)$. 
Diharapkan adanya kerjasama lintas sektoral dalam pemberian materi kesehatan reproduksi remaja dengan menggunakan multimedia.

Kata Kunci: Kesehatan reproduksi; media sederhana; multimedia; pendidikan kesehatan; pengetahuan

\section{PENDAHULUAN}

Masa remaja merupakan masa peralihan antara anak dan dewasa, dimana pada masa itu terjadi banyak perubahan dalam dirinya. Perubahan fisik yang terjadi pada laki-laki yang lebih menonjol adalah tinggi badan yang cepat meningkat, pertumbuhan penis, testis, dan rambut kemaluan. Sedangkan pada wanita yaitu tinggi badan yang cepat meningkat, keluar haid pertama kali, pertumbuhan payudara dan rambut kemaluan (Kusmiran E, 2011).Masa pubertas mempengaruhi beberapa remaja lebih kuat daripada remaja lain, dan mempengaruhi beberapa perilaku lebih kuat daripada perilaku lain. Perubahan masa pubertas mempengaruhi citra tubuh, minat berkencan, dan perilaku seksualnya (Mahfiana, n.d,2009.) Perilaku seksual menurut Sarwono (2006) adalah segala tingkah laku yang didorong oleh hasrat seksual. Berbagai macam bentuk tingkah laku seksual antara lain perasaan tertarik, berkencan, bercumbu dan senggama. Remaja saat ini cenderung melakukan free sex yang tidak sesuai dengan norma agama dan moral masyarakat Indonesia.
Hal ini terjadi karena bentuk informasi yang diperoleh remaja melalui mediamedia elektronik lebih mudah diakses, sehingga norma dan budaya masyarakat sekitar tidak diperhatikan lagi. Berdasarkan data MCR( Mitra Citra Remaja), Kota Bandung tahun 2001-2011, dari 17.776 kasus yang ada lebih banyak terjadi kasus kesehatan reproduksi (perilaku seks pranikah) yaitu kehamilan tidak diinginkan, aborsi, PMS, HIV/AIDS). Perilaku seksual dalam berpacaran remaja dipengaruhi oleh perkembangan era modernisasi. Hal ini terlihat dari perilaku berciuman dan bercumbu sudah dianggap biasa, bahkan ada yang setuju dengan free sex (Mitra Citra Remaja (MCR), 2011)

Hasil penelitian (Badan Kependudukan dan Keluarga Berencana Nasional (BKKBN), 2007 menunjukkan bahwa Jawa Barat diwakili kota Tasikmalaya dan Cirebon. Tasikmalaya 17\% remaja pernah berhubungan seks sebelum nikah dan 6,7\% remaja Cirebon menganut free sexs. Bandung sendiri temuan BKKBN menyebutkan, sekitar $21-30 \%$ remaja melakukan hubungan seks sebelum nikah, 
sedangkan di Cianjur 42,3\% pelajar melakukan hubungan seks pra nikah dengan pasangan yang lebih dari satu (BKKBN, 2007).

Berdasarkan permasalahan di atas berbagai cara telah dilakukan baik dengan adanya peraturan maupun tindakan hukum, akan tetapi masih saja sulit untuk diatasi. Jika dicermati, banyaknya tindakan asusila dan pergaulan bebas yang dilakukan remaja disebabkan oleh berbagai faktor. Salah satu penyebab utamanya yaitu rendahnya pengetahuan seks yang benar baik pada pendidikan formal (sekolah) maupun non-formal (keluarga/orang tua). Kondisi demikian sesuai dengan hasil penelitian oleh NN(2014) di Kota Cirebon, didapatkan hasil bahwa terdapat korelasi yang signifikan antara pengetahuan tentang kesehatan reproduksi dengan perilaku seksual remaja. Selain hal di atas berdasarkan survey pendahuluan yang dilakukan pada SMAN 9 Kota Cirebon tahun 2016, berdasarkan wawancara terhadap guru bimbingan dan konseling, bahwa sejak tahun 2013 terdapat kasus hamil di luar nikah.

Berdasarkan data awal melalui wawancara singkat dengan 20 siswa kelas XI, didapatkan hasil bahwa 15 orang siswa memiliki pengetahuan yang kurang tetang kesehatan reproduksi remaja. Rendahnya pengetahuan merupakan faktor yang mempengaruhi tingginya perilaku seks remaja, karena pengetahuan yang kurang mengenai seks dapat membuat remaja menjadi semakin penasaran bahkan cenderung mencoba sendiri.

Pendidikan kesehatan merupakan usaha atau kegiatan individu, kelompok, dan masyarakat untuk meningkatkan kemampuan baik pengetahuan, sikap, maupun keterampilan dalam mencapai hidup sehat secara optimal (Kadek, 2014). Pendidikan seks (sex education) adalah berbagai informasi tentang seksualitas yang jelas dan benar. Adapun jenis informasi tersebut yaitu pembuahan, kehamilan, persalinan, tingkah laku seksual, hubungan seksual, dan aspek kejiwaan, kesehatan dan kemasyarakatan (Wardani, 2013).Pemberian informasi yang benar dan tepat pada remaja akan berdampak baik terhadap perkembangan jiwa remaja termasuk perilaku seksualnya, karena selain tidak cukupnya informasi mengenai aktifitas seksual, remaja juga berada pada potensi seksual yang aktif serta pengaruh hormonal yang meningkatkan dorongan seksualnya. Proses pendidikan akan berhasil jika dalam proses tersebut menggunakan 
media dan metode yang tepat. Metode dan media yang baik akan memberikan dampak yang efektif dalam mencapai tujuan. Menurut Ybarra, M.L., Emenyonu, N., Nansera, D., Kiwanuka, J. \& Bangsberg, (2007) penyampaian pendidikan dengan menggunakan banyak metode dan media akan lebih efektif meningkatkan pengetahuan siswa dalam pembelajaran.

Multimedia merupakan salah satu cara untuk menyalurkan pesan, baik itu pengetahuan, sikap, dan keterampilan serta dapat meningkatkan rangsangan pikiran, perasaan dan kemauan. Multimedia adalah perpaduan media yang lebih dari dua media yang terdiri dari teks, grafis, gambar, foto, audio, video dan animasi secara terintegrasi. Manfaat multimedia dalam pembelajaran pendidikan kesehatan adalah dapat membuat siswa lebih aktif, meningkatkan kualitas belajar, meningkatkan daya tarik, kemauan, dan pemahaman serta pendalaman terhadap materi yang sulit menjadi lebih cepat dan efektif (Selvi, 2016).

\section{METODE PENELITIAN}

Jenis penelitian adalah eksperimental semu (quasi experimental) dengan rancangan pretest posttest with control group design. Sampel dikelompokkan menjadi dua yaitu kelompok intervensi (multimedia) dan kelompok kontrol (media sederhana). Pada penelitian ini, intervensi dilakukan sebanyak 2 kali baik pada kelompok intervensi maupun kontrol yaitu sebelum intervensi dinamakan pre-test dan setelah perlakuan dinamakan post-test untuk mengetahui peningkatan pengetahuan remaja tentang kesehatan reproduksi.

Populasi dalam penelitian adalah siswa/i kelas XI SMAN 9 di Kota Cirebon yang berjumlah 180 orang. Pengambilan sampel dengan teknik cluster random sampling. Berdasarkan teknik pengambilan sampel tersebut, diperoleh kelas XIA sebagai kelompok intervensi dan kelas XIB sebagai kelompok kontrol dengan jumlah siswa di masing- masing kelas sebanyak 30 orang sehingga jumlah total sampel sebanyak 60 orang. Adapun kriteria inkusi yaitu responden siswa kelas XI, bersedia menjadi responden dan mengikuti kegiatan dari awal sampai akhir, sedangkan kriteria eksklusi nya yaitu siswa-siswi yang tidak hadir dengan alasan sakit/ izin/ tanpa keterangan. Pengumpulan data dilaksanakan selama 2 hari pada kelompok multimedia dan kelompok media sederhana. Multimedia yang diberikan berupa video hak cipta 
BKKBN sedangkan media sederhana yaitu menggunakan power point berupa teks saja.

Pada masing-masing kelompok diawali dengan pre-test kemudian dilanjutkan dengan pemberian materi dengan menggunakan media yang berbeda pada 2 kelompok dan diakhiri dengan post-test. Instrumen yang digunakan adalah kuesioner yang telah dilakukan uji validitas berjumlah 35 pernyataan. Analisis data dalam penelitian ini menggunakan paired $t$ test untuk melihat perbedaan dalam satu kelompok perlakuan dan independent t-test untuk kelompok perlakuan yang berbeda.

\section{HASIL}

Hasil uji statistik berdasarkan data yang diperoleh dari siswa kelas XI di SMA 9 Kota Cirebon baik pada kelompok intervensi (multimedia) maupun kelompok kontrol (media sederhana) disajikan pada Tabel 1 .

Tabel 1 Hasil analisis Peningkatan Pengetahuan Kesehatan Reproduksi Siswa Kelas XI SMAN 9 Kota Cirebon

\begin{tabular}{|c|c|c|c|c|c|c|}
\hline Kelompok & Pengetahuan & Mean & SD & $\mathrm{p}$ & Selisih & $\mathrm{IK}(95 \%)$ \\
\hline \multirow{2}{*}{ Multimedia } & Pre test & 27.50 & 2.09 & \multirow{2}{*}{0.000} & \multirow{2}{*}{5.93} & \multirow{2}{*}{$5.13-6.72$} \\
\hline & Post test & 33.43 & 1.22 & & & \\
\hline \multirow{2}{*}{ Sederhana } & Pre test & 26.53 & 1.75 & \multirow{2}{*}{0.005} & \multirow{2}{*}{1.03} & \multirow{2}{*}{$0.32-1.74$} \\
\hline & Post test & 27.56 & 1.75 & & & \\
\hline
\end{tabular}

Tabel 1 menunjukkan terdapat peningkatan skor pengetahuan antara pre test dan post test pada dua jenis media yang digunakan pada pelaksaaan pendidikan kesehatan.Pada kelompok multimedia rata-rata pengetahuan pada pre test adalah 27.50 dengan standar deviasi 2.09 dan rata-rata pengetahuan pada post test adalah 33.43 dengan standar deviasi 1.22. Nilai p_value 0.000, menunjukkan bahwa skor pengetahuan antara pre test dan post test terdapat peningkatan secara signifikan. Pada media sederhana rata-rata pengetahuan pre test adalah 26.53 dengan standar deviasi 1.75 dan rata-rata pengetahuan post test adalah 27.56 dengan standar deviasi 1.75. Nilai p-value 0.005, menunjukkan bahwa skor pengetahuan antara pre test dan post test terdapat peningkatan secara signifikan.

Tabel 2 menunjukkan bahwa terdapat perbedaan yang bermakna antara pengetahuan pada kelompok multimedia dengan kelompok media sederhana. Nilai rerata kenaikan antara pre-test dan post-test pada kelompok multimedia sebesar 5.93 dengan standar deviasi 2.14 dan nilai 
rerata kenaikan antara pre test dan post test pada kelompok media sederhana sebesar 1.03 dengan standar deviasi 1.90 .
Perbedaan selisih rerata antara kelompok multimedia dengan kelompok media sederhana adalah

Tabel 2 Hasil analisis Perbedaan peningkatan Pengetahuan Pre Test dan Post test pada kelompok Multimedia dan media Sederhana

\begin{tabular}{llllll}
\hline \multirow{2}{*}{ Media } & \multicolumn{5}{c}{ Perubahan Pengetahuan } \\
\cline { 2 - 6 } & Mean & SD & p & Selisih & IK (95\%) \\
\hline Multimedia & 5.93 & 2.14 & 0.000 & 4.93 & $3.88-5.98$ \\
Sederhana & 1.03 & 1.90 & & & \\
\hline
\end{tabular}

\section{PEMBAHASAN}

Hasil penelitian menunjukkan bahwa kedua jenis media yang digunakan dalam proses pembelajaran dapat meningkatkan pengetahuan remaja tentang kesehatan reproduksi. Peningkatan pengetahuan secara statistik ini bermakna bahwa responden memahami materi dan mampu menyerap materi yang diberikan pada saat perlakuan. Hal ini sesuai dengan pernyataan Notoatmodjo (2012) bahwa pengetahuan merupakan hasil dari tahu, dan ini terjadi setelah orang melakukan penginderaan terhadap suatu objek tertentu. Pembelajaran secara bersamasama memotivasi peserta untuk mendalami pengetahuan yang mereka miliki dengan cara mengaktifkan kembali pengetahuan yang dimiliki, mengelola pengetahuan yang kemudian akan mengorganisasikan pengetahuan tersebut sehingga pengetahuan yang diperoleh dapat bertahan erat dalam sistem penyimpanan dan sulit dilupakan.
Sejalan dengan Sullivan R (2009) yang menyatakan bahwa responden telah menyimpan pengetahuan yang diberikan pada saat perlakuan. Belajar khususnya dipengaruhi oleh metode yang digunakan, tetapi pembelajar juga dapat mengambil kelebihan khususnya kemampuan media untuk melengkapi keterampilan pembelajar dan pengetahuan yang dimiliki (Sullivan R, 2009). Hasil penelitian di atas sesuai dengan hasil penelitian Maulana (2009), bahwa pancaindera yang banyak menyalurkan pengetahuan ke otak adalah mata (kurang lebih 75\%- 87\%), sedangkan 13\%- 25\% pengetahuan manusia diperoleh dan disalurkan melalui pancaindera yang lain. Metode pembelajaran dengan menggunakan media dengan memaksimalkan mata (visual) dan telinga (audio) dapat meningkatkan pengetahuan lebih banyak. Oleh sebab itu, penggunaan multimedia dalam pembelajaran akan lebih baik dibandingkan dengan media tunggal 
lainnya atau media yang lebih sederhana. Hasil ini sejalan dengan penelitian Arfan Muhammad.(2010) yang menunjukkan adanya perubahan pengetahuan sebelum dan setelah diberikan pendidikan kesehatan serta multimedia merupakan media yang lebih efektif dibandingkan dengan tatap muka.

Menurut Ybarra, M.L., Emenyonu, N., Nansera, D., Kiwanuka, J. \& Bangsberg, (2007) bahwa dalam penyampaian pendidikan dengan menggunakan banyak metode dan media akan lebih efektif dalam meningkatkan pengetahuan khususnya remaja. Penggunaan metode dan media yang tepat dalam suatu proses pendidikan sangat penting agar sesuai dengan tujuan yang diharapkan. Metode dan media yang baik akan memberikan dampak yang efektif dalam mencapai tujuan pembelajaran.

Penggunaan multimedia dalam pembelajaran merupakan sarana untuk menyampaikan ilmu pengetahuan yang cukup efektif, karena dapat menyampaikan materi secara visual, dengan mengintegrasikan unsur teks, audio, grafik dan animasi. Hal ini senada dikemukakan oleh Mayer, n.d.(2009) bahwa penggunaan multimedia sebagai alat bantu kognisi manusia. Siswa dapat aktif dalam pembelajaran dan dapat mengembangkan kemampuan mereka untuk memahami materi yang dipelajari. Miarso (2007) menyatakan bahwa media pembelajaran merupakan segala sesuatu yang dapat digunakan untuk menyalurkan pesan serta merangsang pikiran, perasaan, perhatian dan kemampuan siswa sehingga dapat mendorong terjadinya proses belajar yang disengaja, bertujuan dan terkendali. Senada juga dengan pendapat Setyosari P (2010) bahwa penggunaan multimedia dalam pembelajaran secara tepat dan bervariasi dapat meningkatkan cara belajar siswa menjadi lebih aktif. Efektifitas multimedia untuk pembelajaran memerlukan penggabungan berbagai media secara hati-hati dengan alasan yang tepat dan mengambil keuntungan dari masing-masing karakteristik media pembelajaran. Tosun menyatakan bahwa mungkin dulu media tidak terlalu berperan penting dalam pembelajaran karena hanya menggunakan papan tulis dan kapur saja, namun dalam perkembangannya media pembelajaran berbasis komputer merupakan alat bantu yang hampir wajib digunakan dalam pembelajaran pada saat ini (Arif dkk, 2011).

Berdasarkan hasil tersebut dapat disimpulkan bahwa pendidikan kesehatan melalui multimedia maupun media 
sederhana dapat meningkatkan pengetahuan tentang kesehatan reproduksi, namun pendidikan kesehatan melalui multimedia lebih efektif untuk meningkatkan pengetahuan tentang kesehatan reproduksi sehingga multimedia dapat dijadikan alternatif bagi tenaga kesehatan memberikan pendidikan kesehatan tentang kesehatan reproduksi remaja.

\section{KESIMPULAN}

1. Terdapat peningkatan skor pengetahuan antara pre-test dan post-test, pada masing- masing kelompok multimedia dan kelompok media sederhana.

2. Terdapat perbedaan yang bermakna antara pengetahuan pada kelompok multimedia dengan kelompok media sederhana. Penggunaan Multimedia lebih efektif dibandingkan dengan penggunaan media sederhana dalam memberikan pendidikan kesehatan reproduksi pada remaja.

\section{REFERENSI}

Arfan Muhammad., W. S. A. \& W. B. (2010). Efektivitas Pendidikan kesehatan Melalui Multimedia Materi KRR dan Tatap Muka di Kelas Terhadap Peningkatan Pengetahuan Kesehatan Reproduksi Remaja. Berita Kedokteran Masyarakat, 26(2), 107-114.
Badan Kependudukan dan Keluarga Berencana Nasional (BKKBN). (2007). Pusat Penelitian dan pengembangan Kependudukan. Bandung, Jawa Barat.

Kadek. (2014). Hubungan Pengetabuan dengan Sikap Remaja tentang Perilaku Seksual Pranikah Pada siswa kelas X di SMA Negeri 1 Manado.

Kusmiran E. (2011). Kesehatan reproduksi remaja dan wanita. Jakarta: Salemba Medika.

Mahfiana, D. (n.d.). Remaja dan Kesehatan Reproduksi. Ponorogo: STAIN Pmorogo Press.

Mayer, R. E. (n.d.). Multimedia Learning. Yogyakarta: Pustaka Pelajar.

Miarso, Y. (2007). Menyemai Benih Teknologi Pendidikan. Computer. https://doi.org/10.1038/cddis.2011 .1

Mitra Citra Remaja (MCR). (2011). Profil Akses Kasus MCR PKBI. Bandung, Jawa Barat.

NN, M. (2014). Hubungan pengetahuan remaja, pendidikan kepala keluarga, struktur keluarga dan pengawasan orang tua dengan perilaku seksual remaja Sekolah Menengah Atas kelas XII di Kota Cirebon. Buletin Media Informasi Poltekkes Kemenkes Tasikmalaya.

Sarwono. (2006). Psikologi Remaja. Psikologi Remaja. https://doi.org/10.1108/09513551 011032482.Bastian

Selvi. (2016). Media Penyuluban Kesehatan Reproduksi Berbasis Animasi dan Multimedia pada Remaja di Badan Kependudukan Keluarga Berencana Nasional (BKKBN). Yogyakarta.

Setyosari P. (2010). Pemanfaatan Media. Malang.

Wardani. (2013). Hubungan Pengetahuan tentang Seks Pra nikah dan sikap terbadap seks pranikah pada SMAN 1 Godong.

Ybarra, M.L., Emenyonu, N., Nansera, D., Kiwanuka, J. \& Bangsberg, D. R. 
Care: Jurnal Ilmiah Ilmu Kesehatan Vol .6, No.3,2018,hal 210-218

(2007). Health information seeking among Mbararan adolescents: results from The Uganda media and you survey'. Health Educ. Res, 23(2), 249258. 